\title{
ANALISIS KEKUATAN ASPAL PEN 60-70 TERMODIFIKASI DENGAN PEMANFAATAN KARET ALAM SIKLIK (CYCLIC NATURAL RUBBER)
}

\author{
Alkhafi Maas Siregar, Rahmatsyah dan Syahril Tahir Parinduri*
}

Jurusan Fisika, Fakultas Matematika dan Ilmu Pengetahuan Alam, Universitas Negeri Medan, Indonesia

\begin{abstract}
Abstrak
Telah dilakukan penelitian tentang analisis kekuatan aspal pen 60-70 termodifikasi dengan pemanfaatan karet alam siklik. Penelitian ini bertujuan untuk mengetahui kekuatan optimum aspal dengan penambahan karet alam siklik (CNR). Sampel dibuat dengan komposisi aspal dan karet alam siklik masing- masing 0, 1, 2 ,3 dan 4 phr. Karet alam digerus dan disaring dengan ukuran 100 mesh dengan ditambahkan compatibilizer Asam Akrilat dan Benzoil Peroksida. Aspal yang digunakan sebanyak 2000 gr (100 phr), karet alam siklik yang digunakan sebanyak $20 \mathrm{gr}(1 \mathrm{phr}), 40 \mathrm{gr}(2 \mathrm{phr}), 60 \mathrm{gr}(3 \mathrm{phr})$ dan $80 \mathrm{gr}$ (4 phr), Asam Akrilat $5 \mathrm{ml}(0,25 \mathrm{phr})$ dan Benzoil Peroksida 0,336 gr (0,0045 phr). Masing-masing sampel yang digunakan telah memenuhi persyaratan sifat fisik aspal yang terdiri dari pengujian penetrasi, pengujian titik lembek, pengujian daktilitas, pengujian berat jenis dan pengujian kehilangan berat. Pada pengujian kekuatan aspal yang meliputi uji density, stability dan flow dengan kadar aspal 5,95\% memiliki kekuatan maksimum dengan nilai uji density 2,418 $\mathrm{gr} / \mathrm{ml}$ pada penambahan $80 \mathrm{gr} \mathrm{CNR}$, nilai uji stability $1.331 \mathrm{Kgf}$ pada penambahan $80 \mathrm{gr}$ CNR, dan nilai uji flow pada aspal murni $2,50 \mathrm{~mm}$. Kesimpulan dari penelitian ini adalah aspal dapat dimodifikasi dengan karet alam siklik (CNR), dengan kekuatan optimum aspal diperoleh pada penambahan $80 \mathrm{gr}$ CNR
\end{abstract}

Kata Kunci: P60-70 Asphalt, Natural Rubber Cyclic, Acrylate Acid, Benzoyl Peroxide.

How to Cite: Alkhafi Maas Siregar, Rahmatsyah dan Syahril Tahir Parinduri, (2015), Analisis Kekuatan Aspal Pen 60-70 Termodifikasi Dengan Pemanfaatan Karet Alam Siklik (Cyclic Natural Rubber), Jurnal Einsten Prodi Fisika FMIPA Unimed, 3 (2): 38-44. 


\section{PENDAHULUAN}

Kementrian

Perencanaan

Pembangunan Nasional, panjang Jalan

Nasional Indonesia pada tahun 2010 mencapai $38.189 .430 \mathrm{Km}$ yang meliputi panjang jalan yang mantap mencapai $31.522 .090 \mathrm{~km}(82,54 \%)$, panjang jalan tidak mantap $6.667 \mathrm{~km} \quad(17,46 \%)$. Komposisi jalan tidak mantap dengan kerusakan ringan mencapai $48,28 \%$ dan kerusakan berat mencapai $51,72 \%{ }^{[1]}$. Hal ini menjadi permasalahan infrastruktur jalan yang menjadi suatu penghambat laju perkembangan suatu Negara, termasuk Indonesia. Hal ini disebabkan oleh keadaan infrastruktur jalan masih rusak dan menjadi masalah bagi para penggunanya.

Aspal merupakan salah satu material pembentuk infrastuktur jalan juga merupakan salah satu bahan komposit yang biasa digunakan dalam proyek konstruksi seperti bangunan, jalan raya, bandara dan tempat parkir. Aspal merupakan material yang digolongkan sebagai pembentuk campuran perkerasan infrastuktur jalan ${ }^{[2]}$.

Material baru yang memungkinkan dicoba untuk dijadikan campuran dalam modifikasi aspal adalah karet alam (Natural Rubber). Karet alam merupakan suatu rantai hidrokarbon poliisopren yang memiliki rumus empiris $(\mathrm{C} 5 \mathrm{H} 8) \mathrm{n}$ dimana $\mathrm{n}$ adalah derajat polimerisasi yang besarnya bervariasi dari satu rantai kerantai yang lain. Hidrokarbon dalam lateks asli berbentuk bulatan-bulatan kecil yang diameter nya kira-kira $0,5 \mu(5.10-5 \mathrm{~cm})$ tersuspensi dalam medium berair atau serum, konsentrasi hidrokarbon sekitar 35 $\%$ dari berat total. ${ }^{[3]}$ Karet alam juga sebagai bahan utama pembuatan Ban, beberapa Alat-alat kesehatan, alat-alat yang memerlukan kelenturan dan tahan goncangan. ${ }^{[4]}$

Penambahan karet alam sebagai material campuran dalam modifikasi aspal penetrasi 60/70 mampu menghasilkan kekuatan yang bagus di dalam campuran aspal sehingga menyebabkan agregat melekat kuat, tetapi juga memiliki tingkat elastisitas yang tinggi dimana jika penelitian ini tidak dilakukan dan dikembangkan maka kerusakan jalan akibat kekuatan material yang tidak optimal akan terus terjadi. Berdasarkan uraian di atas, maka peneliti ingin melakukan analisis terhadap aspal yang dimodifikasi dengan penambahan karet alam siklik.

\section{METODE PENELITIAN}

Penelitian dimulai dari Pembuatan sampel yang dilakukan di Laborarium Kimia Universitas Negeri Medan. Pengujian sampel dilakukan di Laboratorium Balai Penelitian Sistem Pelaksanaan, Pengujian dan, Peralatan (PSP3) Dinas Pekerjaan Umum Medan. Sampel dibuat dengan komposisi aspal dan karet alam siklik masing- masing 0, 1, 2 ,3 dan 4 phr. Karet alam digerus dan disaring dengan ukuran 100 mesh ditambahkan compatibilizer Asam Akrilat dan Benzoil Peroksida. Aspal yang digunakan sebanyak 2000 gr. Setelah sampel selesai sampel diuji persyaratan sifat fisik yang meliputi pengujian penetrasi SNI 06-2456-1991 ${ }^{[5]}$, titik lembek SNI 06-2433-1991 ${ }^{[6]}$, berat jenis dan penurunan nilai berat jenis SNI 06-2441-1991 ${ }^{[7]}$, kehilangan berat dan penurunan kehilangan berat SNI 06-2440$1991^{[8]}$, daktilitas dan penurunan nilai daktilitas SNI 06-2432-1991 ${ }^{[9]}$. Pengujian sifat fisik aspal dilakukan sesuai dengan pedoman standart nasional Indonesia (SNI) setelah memenuhi sifat fisik selanjutnya menguji kekuatan aspal meliputi uji densitas SNI 06-2438-1991 ${ }^{[10]}$, stabilitas SNI 06-2489-1991[11] dan flow SNI 032439-1991 ${ }^{[12]}$ dengan nilai starndart mengacu SNI

Flowchact Penelitian 


\section{HASIL DAN PEMBAHASAN}

Hasil penelitian sifat fisik aspal dilakukan dengan material aspal Iran tipe Pen 60-70. Penelitian ini dilaksanakan di Laboratorium Balai Pengujian Sistem Pelaksanaan

Tabel 1. Sifat Fisik Modifikasi Aspal + AA $+\mathrm{BPO}+\mathrm{CNR}$

\begin{tabular}{|c|c|c|c|c|c|c|c|c|}
\hline 1 & $\begin{array}{l}\text { Penetras } \\
\mathrm{i}, 25{ }^{\circ} \mathrm{C} \text {; } \\
100 \mathrm{gr} ; 5 \\
\text { detik }\end{array}$ & $\mathrm{mm}$ & 53,17 & 51,83 & 47 & 46,5 & $40-59$ & $\begin{array}{l}\text { Meme } \\
\text { nuhi }\end{array}$ \\
\hline 2 & $\begin{array}{l}\text { Titik } \\
\text { Lembek } \\
\text { Aspal }\end{array}$ & ${ }^{0} \mathrm{C}$ & 39,5 & 42 & 42,5 & 44,5 & $30-50$ & $\begin{array}{l}\text { Meme } \\
\text { nuhi }\end{array}$ \\
\hline 3 & $\begin{array}{l}\text { Daktilita } \\
\text { s } 25^{\circ} \mathrm{C} \text {, }\end{array}$ & $\mathrm{cm}$ & 120 & 150 & 150 & 150 & $\begin{array}{l}\text { Min } \\
100\end{array}$ & $\begin{array}{l}\text { Meme } \\
\text { nuhi }\end{array}$ \\
\hline 4 & $\begin{array}{l}\text { Berat } \\
\text { Jenis } \\
\text { Aspal }\end{array}$ & $\begin{array}{l}\mathrm{Gr} \\
\mathrm{ml}\end{array}$ & 1,0246 & 1,0195 & 1,0307 & 1,0928 & $\begin{array}{l}\text { Min } \\
1,0\end{array}$ & $\begin{array}{l}\text { Meme } \\
\text { nuhi }\end{array}$ \\
\hline 6 & $\begin{array}{l}\text { Kehilan } \\
\text { gan } \\
\text { Berat; } 5 \\
\text { jam; } 100 \\
{ }^{0} \mathrm{C}\end{array}$ & $\begin{array}{l}\% \\
\text { berat }\end{array}$ & 2,1492 & 2,3165 & 2,3393 & 2,4003 & $\begin{array}{l}\text { Min } \\
1,0\end{array}$ & $\begin{array}{l}\text { Meme } \\
\text { nuhi }\end{array}$ \\
\hline 7 & $\begin{array}{l}\text { Penetras } \\
\text { i setelah } \\
\text { penurun } \\
\text { an berat, }\end{array}$ & $\begin{array}{l}\% \\
\text { asli }\end{array}$ & 50,3 & 49 & 47,59 & 45,08 & $\begin{array}{l}\text { Min } \\
45\end{array}$ & $\begin{array}{l}\text { Meme } \\
\text { nuhi }\end{array}$ \\
\hline 8 & $\begin{array}{l}\text { Daktilita } \\
\text { s } \\
\text { penurun } \\
\text { an }\end{array}$ & $\begin{array}{l}\% \\
\text { asli }\end{array}$ & 60 & 75 & 75 & 75 & $\begin{array}{l}\text { Min } \\
50\end{array}$ & $\begin{array}{l}\text { Meme } \\
\text { nuhi }\end{array}$ \\
\hline
\end{tabular}

Secara lengkap hasil penelitian dapat dilihat pada tabel 2 . yang telah dilakukan antara aspal dengan CNR dengan campuran masing-masing penambahan $1,2, \quad 3$, dan $4 \mathrm{phr}$ menggunakan compatibilizer Asam Akrilat dan Benzoil Peroksida mampu memberikan pengaruh terhadap sifat fisik aspal dan telah memenuhi SNI, akan tetapi dikarenakan nilai penetrasi menurun sehingga persyaratan sifat fisik aspal disesuaikan dengan SNI nilai Pen 40

Tabel 2. Pengujian Kekuatan Aspal

\begin{tabular}{|c|c|c|c|c|}
\hline \multirow[b]{2}{*}{ Sampel } & \multicolumn{3}{|c|}{ Hasil Pengujian } & \multirow{3}{*}{ Keterangan } \\
\hline & \begin{tabular}{|l}
$\begin{array}{l}\text { Density } \\
\text { (gr/ml) }\end{array}$ \\
\end{tabular} & $\begin{array}{l}\text { Stability } \\
(\mathrm{Kg})\end{array}$ & \begin{tabular}{|l|} 
Flow \\
$(\mathrm{mm} /$ menit $)$
\end{tabular} & \\
\hline SNI & Min - 2,00 & Min - 800 & Min - 2,00 & \\
\hline $\begin{array}{l}\text { Aspal } \\
\text { Murni }\end{array}$ & 2,300 & 921 & 2,50 & Memenuhi \\
\hline $\begin{array}{l}\text { Aspal + } 20 \\
\text { gr Karet } \\
\text { Alam } \\
\text { Siklik }\end{array}$ & 2,342 & 942 & 2,47 & Memenuhi \\
\hline $\begin{array}{l}\text { Aspal }+40 \\
\text { cua Karet } \\
\text { Alam } \\
\text { Siklik }\end{array}$ & 2,379 & 1.075 & 2,35 & Memenuhi \\
\hline
\end{tabular}




\begin{tabular}{|l|l|l|l|l|}
\hline $\begin{array}{l}\text { Aspal + 60 } \\
\text { gr Karet }\end{array}$ & 2,384 & 1.270 & 2,31 & Memenuhi \\
$\begin{array}{l}\text { Alam } \\
\text { Siklik }\end{array}$ & & & & \\
\hline $\begin{array}{l}\text { Aspal + 80 } \\
\text { gr Karet }\end{array}$ & 2,418 & 1.331 & 2,27 & Memenuhi \\
$\begin{array}{l}\text { Alam } \\
\text { Siklik }\end{array}$ & & & & \\
\hline
\end{tabular}

\section{Pengaruh Penambahan Karet Alam Siklik Tehadap Berat Isi (densitas)}

Dari Gambar di bawah
menunjukkan bahwa penambahan CNR menyebabkan terjadinya perubahan nilai densitas aspal. secara umum nilai densitas aspal mengalami peningkatan dengan penambahan CNR

Gambar 1. Pengaruh Penambahan Karet Alam Siklik Tehadap Berat Isi (densitas).

\section{Pengaruh Penambahan Kadar Karet Alam Siklik Terhadap Stabilitas.}

Pemeriksaan stabilitas diperlukan untuk mengukur ketahanan benda uji terhadap beban, untuk mendapatkan temperatur terpanas di lapangan, maka sebelum pemeriksaan benda uji dipanaskan terlebih dahulu selama 30 atau 40 menit dengan temperatur $600^{\mathrm{C}}$ di dalam water bath.

Gambar 2. Pengaruh Penambahan Karet Alam Siklik Tehadap Stabilitas

\section{Pengaruh Penambahan CNR Tehadap Nilai Flow}

Campuran

Nilai flow dapat dibaca pada flowmeter dibaca pada nilai arloji pengukur proving ring dibaca pada saat keruntuhan, nilai flow digunakan untuk mengukur deformasi yang terjadi akibat beban

Gambar 1. Pengaruh Penambahan Karet Alam Siklik Tehadap flow

\section{PEMBAHASAN}

Sukirman $^{[3]}$ menyatakan bahwa baik tidaknya campuran aspal dapat dilihat dari pengaruh variasi bahan tambah aspal terhadap sifat Marshall yang meliputi Density, Stability, Flow, untuk aspal ditambah CNR, Asam Akrilat dan Benzoil Peroksida (Aspal-CNR-AA-BPO) adalah sebagai berikut:

1. Densitas; penambahan CNR pada campuran aspal berpengaruh terhadap nilai densitas aspal dimana penambahan CNR mengakibatkan nilai densitas (berat isi) aspal semakin meningkat Hal ini bisa terjadi karena ikatan siklik dari CNR terhadap aspal membuat aspal lebih kuat untuk berinteraksi dengan agregat. Penelitian sebelumnya dilakukan oleh Ritonga $^{[13]}$ memodifikasi aspal menggunakan karet alam siklik dengan variasi yang berbeda menyebabkan nilai densitas meningkat sesuai dengan kadar aspal yang ditambah, semakin tinggi kadar aspal maka nilai densitas semakin meningkat

2. Stabilitas; penambahan CNR pada campuran aspal berpengaruh terhadap nilai stabilitas. Campuran AspalCNR-AA-BPO mencapai keadaan optimum pada kadar aspal 5,92\%. Nilai stabilitas Aspal-CNR-AA-BPO tertinggi berada pada penambahan 80 gr CNR. Hal ini disebabkan oleh turunnya nilai penetrasi dan naiknya titik lembek. Selain itu CNR dapat meningkatkan kohesi (ikatan) antara aspal dan agregat menjadi semakin baik. Hasil penelitian ini sesuai dengan hasil penelitian Cubuk $^{[14]}$ yang menyatakan bahwa penambahan resin dapat meningkatkan nilai stabilitas aspal.

3. Flow; penambahan CNR pada campuran aspal berpengaruh terhadap nilai flow. Hasil pengujian menunjukkan bahwa nilai flow tertinggi ditunjukkan pada campuran aspal murni. Perubahan ini berhubungan dengan perubahan yang terjadi pada nilai penetrasi dan titik lembek. Sesuai dengan pernyataan Sukirman $^{[3]}$ yaitu adanya perpaduan kekerasan antara sifat fisik kedua 
material menyebabkan aspal mempunyai viskositas tinggi sedangkan CNR mempunyai sifat elastis. Penelitian sebelumnya juga dilakukan oleh Achmad ${ }^{[15]}$ yang menyatakan bahwa penambahan polimer berpengaruh terhadap nilai flow. Penelitian Wirahaji ${ }^{[16]]}$ menunjukkan bahwa aspal Iran pen 60-70 memiliki kadar optimum yaitu $5,92 \%$ dalam campuran aspal. Hasil optimum nilai uji density yaitu 1,098 $\mathrm{gr} / \mathrm{ml}$, nilai uji stability yaitu 1,331 kgf, dan nilai uji flow yaitu $2,50 \mathrm{~mm}$ diperoleh dengan penambahan $4 \mathrm{phr}$ (80 gr) CNR.

\section{KESIMPULAN}

Adapun kesimpulan yang dari penelitian ini yaitu terjadi perubahan karakteristik aspal modifikasi pada penambahan CNR (Cyclic Natural Rubber):

1. Aspal Iran pen $60 / 70$ telah dapat dimodifikasi dengan penambahan karet alam siklik (Cyclic Natural Rubber) dengan variasi 1 phr (20 gr), 2 phr (40 gr), 3 phr (60 gr), dan 4 phr (80 gr).

2. Aspal termodifikasi dengan karet alam siklik (CNR) dengan campuran sebanyak 1 phr, 2 phr, 3 phr dan 4 phr telah memenuhi uji persyaratan sifat fisik aspal, selanjutnya diperoleh ;

a. Pada analisis kekuatan, untuk nilai uji density didapatkan peningkatan dari 2,300 $\mathrm{gr} / \mathrm{ml}$ (aspal murni) menjadi 2,418 gr/ml (campuran 80 gr CNR). Untuk nilai stabilitas aspal, didapatkan peningkatan dari $921 \mathrm{Kgf}$ (aspal murni) menjadi $1.331 \quad \mathrm{Kgf}$ (campuran 80 gr CNR). Dan untuk nilai flow, didapatkan nilai tertinggi yaitu $2,50 \mathrm{~mm}$ (aspal murni) sedangkan nilai flow terendah ialah 2,27 $\mathrm{mm}$ (campuran 80 gr CNR). b. Pada analisis kualitas menurut SNI, aspal Iran penetrasi 60-70 setelah dimodifikasi dengan CNR dinyatakan layak (baik) untuk digunakan.

3. Kekuatan optimum dengan nilai uji density yaitu $1,098 \mathrm{gr} / \mathrm{ml}$, nilai uji stability yaitu $1,331 \mathrm{Kgf}$, dan nilai uji flow yaitu 2,50 $\mathrm{mm}$ diperoleh dengan penambahan 4 phr (80 gr) CNR.

\section{DAFTAR ACUAN}

[1] Badan Perencanaan Pembangunan Nasional, (2012), Pembangunan Daerah Dalam Angka 2012, Kementerian Pembangunan Nasional, Jakarta.

[2] Treloar, (1967), The Physics of Rubber Elasticity Third Editon, Oxford University Press. England.

[3] Sukirman, S. (2012). Beton Aspal Campuran Panas. Edisi Kedua, Itenas, Bandung

[4] Suwardin, D. (1989). Teknik Pengendalian Limbah Pabrik Karet. Jurnal. Lateks Wadah Informasi dan Komunikasi Perkebun Karet, 4 (2) : 2834. SNI 06-2432-1991, Metode Pengujian Daktilitas Bahan-Bahan Aspal, Badan Standardisasi Nasional, Jakarta

[5] SNI 06-2456-1991, Metode Pengujian Penetrasi Bahan - Bahan Bitumen, Badan Standardisasi Nasional, Jakarta.

[6] SNI 06-2433-1991, Metode Pengujian Titik Nyala Dan Titik Bakar Dengan Cleveland Open Cup, Badan Standardisasi Nasional, Jakarta.

[7] SNI 06-2441-1991, Metode Pengujian Berat Jenis Aspal, Badan Standardisasi Nasional, Jakarta.

[8] SNI 06-2440-1991, Metode Pengujian Kehilangan Berat Minyak dan Aspal, Badan Standardisasi Nasional, Jakarta.

[9] SNI 06-2432-1991, Metode Pengujian Daktilitas Bahan-Bahan Aspal, Badan Standardisasi Nasional, Jakarta. 
[10] SNI 06-2438-1991, Metode

Pengujian kadar aspal (densitas), Badan

Standardisasi Nasional, Jakarta

[11] SNI 06-2489-1991, Metode

Pengujian stabilitas aspal, Badan

Standardisasi Nasional, Jakarta

[12] SNI 03-2439-1991, Metode

Pengujian marshall untuk nilai flow,

Badan Standardisasi Nasional, Jakarta.

[13] Ritonga Winsyahputra. (2013).

Modifikasi Aspal dengan Menggunakan

Karet Alam Siklit (Cyclic Natural

Rubber),Tesis, FMIPA, Universitas

Sumatera Utara (USU), Medan.

[14] Cubuk MK, 2010, Improvement of bitumen performance with epoxy resin, Elsevier, Fuel 88 (2009) 1324 1328.

[15] Achmad Djedjen, Kusumo, Dampak Penambahan Polimer Terhadap Karakterisasi Beton Aspal, Jurnal Politeknik Negeri Jakarta, Vol 10 No 1 Januari 2011

[16] Wirahaji, 2012, Analisis Kadar Aspal Optimum Laston Lapis Aus Pada Ruas Jalan Simpang Sakah - Simpang Blahbatuh, Jurnal Ilmiah Teknik Sipil Vol. 16, No. 2, FT UNHI. 